Vol. 24, No. 1, Januari 2021, hlm. 124-133

p-ISSN: 1410-9344; e-ISSN: 2549-5631

homepage: http://journals.ums.ac.id/index.php/warta

\title{
Pengenalan Teknologi Kloning Melalui Media Pembelajaran Interaktif "Lakon" pada Siswa SMA di Kota Yogyakarta
}

\author{
Arif Bimantara ${ }^{1}$, Ade Putranto Prasetyo Wijiharto Tunggali ${ }^{2}$, Erwin Rasyid ${ }^{2}$ \\ ${ }^{1}$ Program Studi Bioteknologi, Universitas 'Aisyiyah Yogyakarta \\ ${ }^{2}$ Program Studi Komunikasi, Universitas 'Aisyiyah Yogyakarta \\ email : 'bimantara.arif@unisayogya.ac.id, ²ade.putra.tunggali@unisayogya.ac.id
}

\section{Article Info}

Submitted: 5 April 2020

Revised: 3 June 2020

Accepted: 16 November 2020

Published: 24 December 2020

Keywords : Hoax, Cloning

Technology, Interactive Learning

Media, Genetic Engineering
Kata Kunci : Hoax, Teknologi Kloning, Media Pembelajaran Interaktif, Rekayasa Genetika

\begin{abstract}
Interactive learning media becomes one of the effective learning tools for introducing a new insight to students. The aim of this community service in this article is to introduce the basic technique on cloning as one of the genetic engineering technologies through interactive learning media to high school students in Yogyakarta city. This activity is expected to provide students with a correct understanding of cloning technology amid the hoax informations about this technology. The interactive media used is called the Labirin Kloning or abbreviated "Lakon" in the form of a puzzle consisting of material used in the process of genetic material cloning. Pretest and post-test was done to evaluate the effectiveness of this learning media. Evaluation results show that students' understanding of cloning technology through the Lakon has significantly increased as indicated by an increase in the average number of students who answered correctly at the time of the pre-test (45.86\%) compared to the post test (85.71\%). The Lakon is expected to be a prototype of interactive learning media for teachers in instilling new knowledge in their students.
\end{abstract}

Abstrak
Media pembelajaran interaktif menjadi salah satu perangkat
pembelajaran yang efektif dalam asimilasi pengetahuan baru kepada
siswa. Pengabdian masyarakatdalam artikelini bertujuan mengenalkan
dasar ilmu kloning sebagai salah satu teknologi rekayasa genetika
melalui media pembelajaran interkatif kepada siswa SMA di Kota
Yogyakarta. Kegiatan ini diharapkan mampu memberikan pemahaman
yang benar kepada siswatentang teknologi kloning di tengah maraknya
berita hoax mengenai teknologi ini. Media interaktif yang digunakan
bernama Labirin Kloning atau disingkat "Lakon" yang berbentuk
puzzle terdiri dari bahan yang digunakan dalam proses kloning
materi genetik. Pre-test dan post-test dilakukan untuk mengevaluasi
keefektifan media pembelajaran ini. Hasil evaluasi menunjukkan
bahwa pemahaman siswa mengenai teknologi kloning melalui Lakon


meningkat secara signifikan ditunjukkan dengan peningkatan ratarata jumlah siswa yang menjawab dengan benar pada saat dilakukan pre-test $(45,86 \%)$ dibandingkan dengan post test $(85,71 \%)$. Lakon diharapkan dapat menjadi prototype media pembelajaran interaktif bagi para guru dalam menanamkan ilmu pengetahuan baru kepada siswanya

\section{PENDAHULUAN}

Kemajuan ilmu pengetahuan dan teknologi saat ini menyebabkan semakin berkembangnya mata pelajaran di level sekolah termasuk jenjang Sekolah Menengah Atas (SMA/MA/SMK). Berbagai mata pelajaran sekolah tentunya selalu fleksibel dalam mengikuti perkembangan zaman seperti ilmu bilogi yang saat ini lebih mengarah kepada ilmu aplikatif yaitu bioteknologi. Ilmu rekayasa genetika merupakan salah satu cabang ilmu bioteknologi yang selalu berkembang seiring dengan penemuan teknologi baru pada bidang tersebut. Kloning merupakan salah satu teknologi dalam rekayasa genetika yang memungkinkan manusia untuk membuat duplikat baik dalam skala molekuler bahkan hingga skala individu.

Kloning adalah suatu teknik perbanyakan suatu sekuen gen (DNA) dengan cara menggabungkan suatu sekuen DNA makhluk hidup dengan DNA makhluk hidup lain. Penerapan kloning pada hewan dan tanaman telah menjawab banyak pertanyaan dalam bidang biologi dasar (Reece et.al., 2014). Teknologi ini telah banyak digunakan saat ini untuk berbagai keperluan antara lain untuk membuat tanaman atau hewan transgenik, sintesis enzim yang digunakan dalam keperluan medis, terapi gen sebagai alternatif pengobatan, pembuatan protein rekombinan yang dapat digunakan dalam berbagai hal dan lain sebagainya. Menurut Ayala (2015), teknologi kloning di masa depan akan sangat bermanfaatn dalam pengembangan transplantasi organ, penyembuhan jaringan dan sel syaraf, dan manfaat di bidang kesehatan yang lain. Akan tetapi teknologi ini seringkali disalah persepsikan oleh masyarakat awam. Siswa SMA/MA/SMK menjadi salah satu subjek yang masih banyak mengalami kesalahan persepsi tersebut. Padahal ilmu mengenai kloning akan sangat bermanfaat sebagai bekal ilmu dasar ilmiah dalam mengembangkan sumber daya alam di Indonesia. Penguasaan pemahaman mengenai metode kloning akan menumbuhkan jiwa kreativitas pada diri siswa. Di Indonesia sendiri telah banyak dilakukan penelitian dengan menggunakan metode kloning. Metode ini banyak digunakan dalam bidang pemuliaan tanaman dan hewan, peningkatan kualitas komoditas pertanian, peningkatan kualitas kesehatan serta kelestarian lingkungan. Akan tetapi produk kloning masih belum banyak dikomersialisasikan karena masih ada beberapa regulasi pada tataran pemerintah yang masih belum diresmikan saat ini (Prasetya, 2019).

Kloning merupakan topik yang sangat menarik untuk diulas oleh media terutama dengan ide berupa duplikasi hewan yang sudah dewasa yang mendukung ide lain untuk duplikasi manusia dewasa (Wulff, 2001). Mayoritas masyarakat mempercayai bahwa kloning selalu berkaitan dengan perbanyakan makhluk hidup seperti penciptaan manusia dan hewan buatan. Film dokumenter, film popular, dan penyajian berita mengenai kloning di media masa sering kali memposisikan teknologi ini sebagai kemajuan yang mengancam keselamatan manusia atau bisa mengubah struktur sosial manusia dibandingkan dengan pemberitaan mengenai kebermanfaatanya (Maio, 2006). Hal tersebut menyebabkan tersebarnya informasi bahwa kloning adalah suatu teknik yang melanggar aturan kemanusiaan dan agama. Informasi tersebut berkebalikan dengan fakta bahwa teknologi kloning memiliki banyak manfaat dibandingkan dengan kerugianyang ditimbulkan. Klotzko (2004) dalam bukunya mencontohkan bahwa teknologi kloning yang dipercaya menyalahi aturan karena dalam percobaannya mengorbankan banyak sampel uji, dalam kasus kelainan reproduksi, teknologi kloning jauh lebih aman dibandingkan dengan reproduksi manusia secara alami. Oleh karena itu perlu dilakukan suatu sosialisasi mengenai dasar dan 
perkembangan teknologi kloning berdasarkan informasi yang dapat dipertanggungjawabkan sumbernya dengan media dan teknik komunikasi yang tepat sehingga masyarakat tidak terjebak mempercayai informasi salah yang telah banyak beredar mengenai teknologi ini.

Atas latar belakang ketidaksesuaian informasi yang banyak beredar di masyarakat mengenai teknologi kloning, maka perlu dilakukan pendekatan yang tepat untuk mengasimilasi pemahaman mengenai teknologi tersebut terutama kepada siswa SMA/MA/SMK. Kegiatan pengabdian masyarakat yang dilakukan dalam artikel ini mencoba mengenalkan kembali teknologi kloning menggunakan media interaktif pembelajaran kloning dengan nama Labirin Kloning atau disingkat "Lakon". Media ini berbentuk suatu puzzle yang terdiri dari alat dan bahan yang diperlukan untuk melakukan suatu kloning sederhana di tingkat molekuler. Bentuk puzzle dipilih agar peserta pengabdian berperan aktif dan ilmu yang diberikan akan lebih mudah terasimilasi. Metode pembelajaran akan sangat berpengaruh pada tingkat pemahaman peserta didik (Hammond et.al., 2020). Media pembelajaran interaktif tersebut dikembangkan untuk mengantisipasi pemahaman tidak benar menganai teknologi kloning seperti mengubah takdir dari Tuhan dan menciptakan makhluk hidup baru yang mendahului takdir Tuhan atau kesalahan pemahaman konsep mengenai cloning yang lain. Target utama media pembelajaran "Lakon" ini adalah siswa SMA yang merupakan generasi milenial di mana masih dalam usia transisi menuju dewasa sehingga perlu bekal yang cukup terutama pemahaman yang benar mengenai perkembangan teknologi saat ini khususnya teknologi kloning. Melalui "Lakon" diharapkan civitas akademik di tingkat SMA mampu memiliki pemahaman yang benar mengenai kloning dan menyebarluaskan informasi yang sebenarnya mengenai teknologi yang banyak memberikan manfaat ini.

\section{METODE}

Metode pelaksanaan program pengabdian masyarakat ini menggunakan metode komunikasi persuasif (stimulus-response). Istilah komunikasi atau communication berasal dari bahasa latin yaitu communicates yang berarti berbagi atau menjadi milik bersama. Communication memiliki kata sifat yaitu communis yang bermakna umum atau bersama-sama, dapat dikatakan, bahwa komunikasi menurut Lexicographer (ahli kamus bahasa), menunjukkan pada upaya yang bertujuan berbagi untuk mencapai kebersamaan (Fajar, 2009). Dalam kajian ilmu komunikasi, teori tentang proses komunikasi dikemukakan oleh Harold D. Laswell (Nurudin, 2016) menyatakan "who says what in which channel which what effect". Proses komunikasi yang didasarkan teori tersebut melahirkan beberapa metode, diantaranya metode komunikasi persuasif. Model tersebut tim aplikasikan pada rentetan kegiatan pengabdian masyarakat dimulai dari pembentukan tim, eksekusi kegiatan hingga evaluasi. Pengenalan "Lakon" ini terdiri dari 3 tahapan yaitu persiapan, pelaksanaan dan evaluasi.

\section{Persiapan}

Pada tahap ini, kegiatan yang dilakukan yaitu mengurus perizinan dalam melakukan pengabdian masyarakat, melakukan konsolidasi dengan sasaran, serta penyusunan materi dan persiapan alat bahan untuk kegiatan.

1. Perizinan

Perizinan dalam hal ini berkenaan dengan kesediaan mitra, yaitu MA Muhammadiyah Yogyakarta, untuk dijadikan tempat pelaksanaan pengabdian masyarakat tentang pengenalan teknologi kloning menggunakan media pembelajaran Lakon.

2. Konsolidasi dengan sasaran

Konsolidasi dengan sasaran, dalam hal ini pengurus MA Muhammadiyah Yogyakarta dan perwakilan siswa kelas XII, sangat diperlukan untuk memperkuat hubungan mitra kerjasama yang telah terwujud melalui perizinan. Konsolidasi mencakup pengamatan kondisi di lapangan dan melakukan diskusi dengan pihak sekolah dan perwakilan siswa kelas XII mengenai kebutuhan serta permasalahan yang dihadapi terkait teknis pengabdian yang akan dilaksanakan. Hal tersebut dilakukan agar pengabdian masyarakatyang dilakukan benar-benar sesuai dengan kebutuhan.

3. Penyusunan materi

Berdasarkan hasil konsolidasi dengan pihak SMA Muhammadiyah Yogyakarta dan 
perwakilan siswa kelas XII, berbagai materi yang akan digunakan untuk mendukung pelaksanaan penyuluhan dan pelatihan dikumpulkan. Studi pustaka dilakukan untuk mencari dan membandingkan keefektifan masing-masing metode yang akan diaplikasikan dalam kegiatan pengabdian masyarakat.

4. Persiapan alat bahan

Persiapan berbagai alat bahan yang mendukung pelaksanaan pengenalan teknologi kloning mencakup : LCD proyektor, laptop, plastisin, gunting, stiker, kertas karton, pewarna, dan video interaktif mengenai penerapan "Lakon" dalam pengenalan teknologi kloning.

\section{Pelaksanaan}

\section{Pre-Test}

Tahapan ini dilaksanakan selain untuk mengetahui kemampuan awal siswa juga digunakan sebagai perbandingan pemahaman siswa setelah dilakukan sosialisasi "Lakon" guna evaluasi program. Topik yang diujikan dalam pre-test ini adalah kesan siswa terhadap kata kloning, pengertian kloning, metode kloning, kerugian kloning, manfaat kloning, hukum kloning dan implementasi kloning yang mereka ketahui.

2. Tahap penyuluhan pentingnya menjadi generasi anti-hoax

Pada tahap ini akan diadakan penyuluhan kepada siswa MA Muhammadiyah Yogyakarta mengenai pentingnya menghindari penyebaran berita hoax di masyarakat sekaligus menjadi agen pemberantasnya. Pengetahuan mengenai pentingnya menjadi generasi anti-hoax sangat bermanfaat bagi siswa sehingga terlatih menjadi pribadi yang kritis dan tidak mudah terpengaruh oleh lingkungan yang buruk.

3. Tahap penyuluhan mengenai sejarah dan perkembangan teknologi kloning

Pemahaman yang benar mengenai teknologi kloning sangat penting dimiliki oleh masyarakat agar terhindar dari budaya anti-kemajuan. Beberapa orang masih beranggapan negatif mengenai penerapan teknologi kloning. Melalui penyuluhan ini diharapkan siswa dapat memahami dengan benar dasar-dasar teknologi kloning beserta perkembangannya saat ini.

4. Tahap pengenalan teknologi kloning melalui media pembelajaran interaktif Lakon

Praktik "Lakon" dilakukan agar siswa dapat lebih mudah memahami prinsip dasar teknologi tersebut. Siswa akan mendapatkan gambaran yang lebih jelas mengenai teknologi kloning dengan melakukan simulasi didampingi oleh tim pelaksana pengabdian masyarakat. Selain itu, praktek langsung juga akan membuat siswa akan lebih lama mengingat materi yang diberikan selama kegiatan jika dibandingkan dengan hanya dilakukan pemberian teori saja. Siswa akan dibagi menjadi 5 kelompok agar penyerapan materi praktek berjalan lebih efisien. Halhal yang akan dilakukan pada tahap ini antara lain:

a. Setiap kelompok akan didampingi oleh satu pendamping dari tim pengabdian

b. Pembagian media pembelajaran interkatif Lakon berupa puzzle yang berisi gambaran beberapa bahan yang digunakan dalam teknologi kloning, antara lain : vektor kloning, DNA target, enzim restriksi endonuklease, enzim ligase, vektor transformasi, dan beberapa salinan dari plasmid yang telah disisipi DNA.

c. Tim pendamping akan melakukan review ulang mengenai dasar kloning dan menjelaskan alat serta bahan yang akan digunakan dalam simulasi tersebut.

d. Siswa akan diarahkan untuk melakukan praktek simulasi langsung oleh tim pendamping (Gambar 2)

e. Video interaktif akan ditampilkan di akhir sesi praktek simulasi sebagai bahan review materi dan praktik simulasi yang dilakukan sebelumnya.

f. Siswa akan diberikan waktu untuk mengerjakan soal-soal terkait materi dan praktek simulasi yang dilakukan 
sebagai bahan evaluasi (post test) keefektifan metode pembelajaran.

g. Pengumpulan nomor kontak media sosial Whatsapp siswa untuk dibentuk suatu grup yang akan digunakan sebagai salah satu media penyampaian update informasi mengenai teknologi kloning dan teknik molekuler lainnya kepada siswa, sehingga siswa selalu mengingat materi yang diberikan ketika penyuluhan dan mendapatkan gambaran mengenai kemajuan IPTEK saat ini.

Pelaksanaan praktek simulasi-persuasif Lakon diharapkan mampu mengefisienkan proses transfer pemahaman teknologi kloning kepada siswa. Kegiatan simulasi tersebut dilakukan dengan melibatkan seluruh peserta kegiatan menggunakan bahan dan alat yang sederhana sehingga lebih mudah dipahami seperti yang diilustrasikan pada Gambar 2. Pelaksanaan kegiatan pengabdian ini membutuhkan waktu 4 bulan dimulai dari tahapan perizinan hingga evaluasi. Adapun timeline pelaksanaan pengabdian ditunjukkan oleh Tabel 1.

\section{HASIL DAN PEMBAHASAN}

Kegiatan pengabdian masyarakat yang dilakukan diharapkan mampu menciptakan agen-agen milenial pembawa pemahaman keilmuan yang benar untuk dapat menyebarkan literasi tentang kloning dan keilmuannya. Domba dolly merupakan salah satu penelitian di bidang kloning yang fenomenal di dunia. Prinsip perangkaian domba dolly adalah dengan menggabungkan inti sel dewasa dari domba yang satu (donor inti sel) dengan sel telur domba yang lain yang inti selnya sudah dikeluarkan. Individu yang akan terlahir akan menyerupai individu pendonor inti sel dengan kesamaan materi genetik yang identik. Dalam perkembangannya, teknologi kloning tidak hanya ditujukan untuk pengembangan individu baru seperti domba dolly, tetapi telah mencapai ke arah yang lebih substansial yaitu molekuler. Kloning pada aras molekuler memungkinkan manusia memproduksi protein atau molekul lainnya dalam skala besar dalam waktu yang cepat dengan biaya yang relatif murah. Pengembangan tersebut didasari pada penyisipan gen penyandi protein yang diinginkan ke dalam vektor plasmid. Plasmid adalah materi genetik selain DNA inti yang biasa terdapat di dalam bakteri. Saat ini plasmid sudah dikomersialkan untuk tujuan kloning ditingkat molekuler yang lebih dikenal dengan nama vektor plasmid. Vektor plasmid yang telah disisipi gen lain kemudian dimasukkan ke dalam bakteri yang bertugas memproduksi protein yang disandi oleh gen tersebut. Bakteri tersebut dapat dikembangbiakkan secara masal dalam waktu singkat dan biaya yang rendah. Ketika mencapai jumlah yang yang diinginkan, bakteri dipanen dan diekstraksi proteinnya dan dimurnikan sehingga didapatkan protein yang diinginkan. Protein yang dihasilkan dari proses ini disebut sebagai protein rekombinan. Sebagai tambahan informasi, enzim, dan hormon adalah contoh protein yang dapat diproduksi dengan cara ini. Dengan cara ini, manusia saat ini dapat memproduksi hormon insulin untuk terapi penyakit diabetes dalam jumlah besar dalam waktu singkat tanpa harus ektraksi hormon insulin dari pankreas babi. Kloning sebagai salah satu teknologi rekayasa genetika telah digunakan dalam berbagai tujuan saat ini (Souii et.al., 2013). Proses kloning yang diejawantahkan dalam bentuk media pembelajaran interaktif Lakon diilustasikan pada Gambar 1.

Tabel 1. Timeline Pelaksanaan Pengabdian

\begin{tabular}{|c|c|c|c|c|c|c|c|c|c|c|c|c|c|c|}
\hline \multirow{2}{*}{ Kegiatan } & \multicolumn{4}{|c|}{ Mei } & \multicolumn{4}{|c|}{ Juni } & \multicolumn{4}{|c|}{ Juli } & \multicolumn{2}{|c|}{ Agustus } \\
\hline & 1 & 2 & 3 & 4 & 1 & 2 & 3 & 4 & 1 & 2 & 3 & 4 & 1 & 2 \\
\hline Perizinan & & & & & & & & & & & & & & \\
\hline Konsolidasi & & & & & & & & & & & & & & \\
\hline Penyusunan Materi & & & & & & & & & & & & & & \\
\hline Persiapan & & & & & & & & & & & & & & \\
\hline Pelaksanaan & & & & & & & & & & & & & & \\
\hline
\end{tabular}




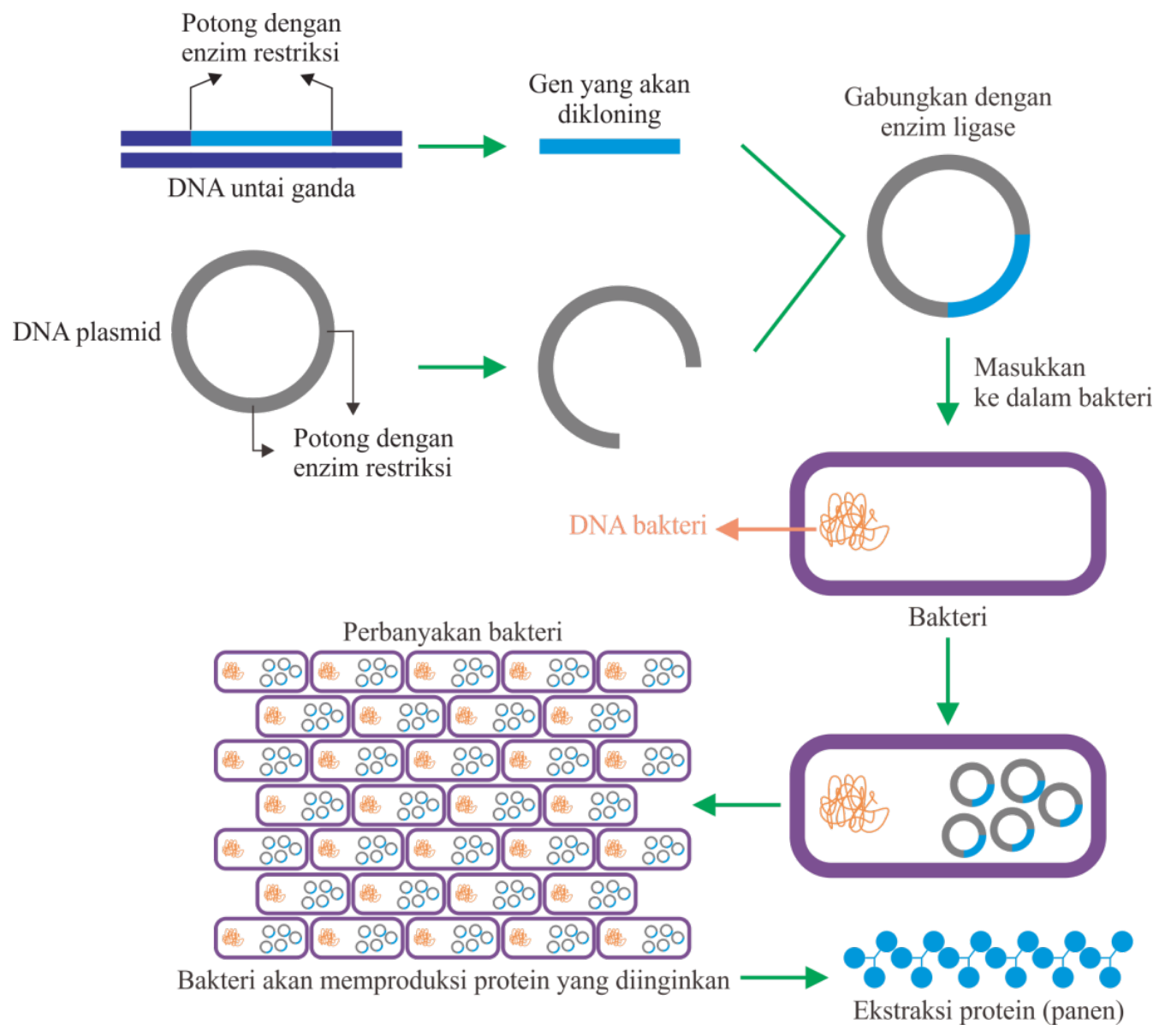

Gambar 1. Ilustrasi Proses Kloning DNA

Teknologi DNA rekombinan yang mengizinkan manusia dapat memproduksi proteinyangdiperlukandaripotongangendengan kendali penuh pada mulanya hanyalah sebuah imajinasi peneliti di bidang bioteknologi (Khan et.al., 2016). Saat ini teknologi kloning sudah semakin pesat seiring dengan perkembangan perangkat pendukung yang telah diciptakan. Proses kloning pada Gambar 1 terlalu rumit jika disampaikan hanya dengan penyampaian teori atau diskusi. Siswa memerluka suatu media yang lebih menarik dari sekadar penyampaian teori. Media pembelajaran interaktif yang melibatkan siswa secara langsung dalam simulasi dapat menyederhanakan teori kloning tersebut tanpa menghilangkan substansi inti dari teknologi tersebut. Lakon dalam bentuk puzzle bertujuan untuk menanamkan pemahaman teknologi kloning tersebut dengan lebih mudah dan sederhana. Komponen yang diperlukan dalam proses kloning tersebut terwujud dalam puzzle Lakon yang diilustrasikan pada Gambar 2.
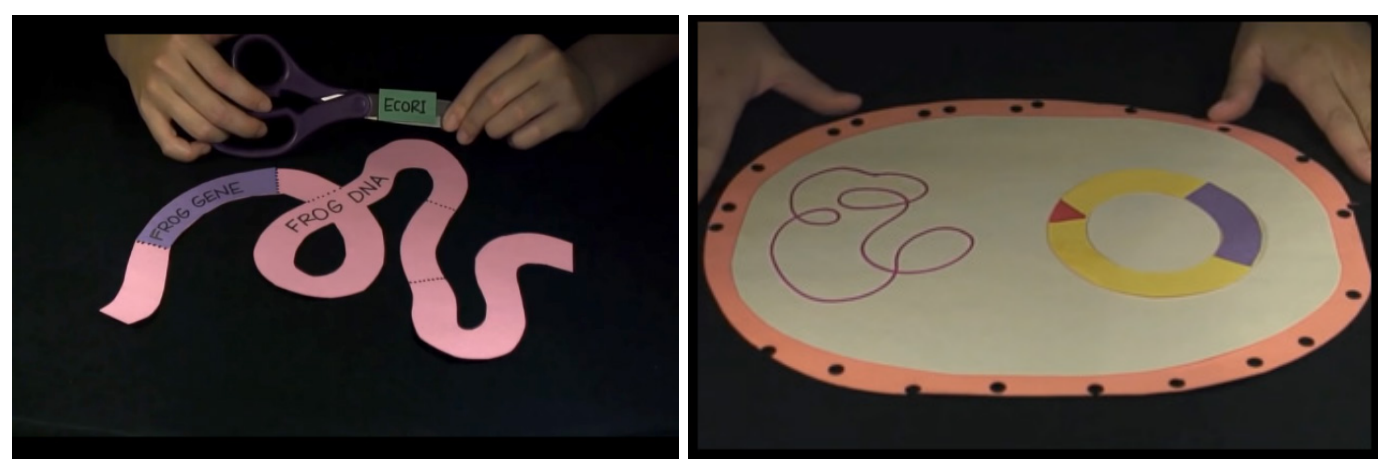

Gambar 2. Media Pembelajaran Interkatif Lakon 
Kegiatan pengabdian masyarakat diawali dengan melakukan pre-test untuk mengetahui pemahaman awal siswa terhadap teknologi kloning. Rata-rata pemahaman siswa dari tujuh soal yang diberikan pada saat pre-test adalah $45,86 \%$. Jawaban yang salah paling banyak terdapat pada soal pertama (P1) mengenai kesan siswa terhadap teknologi kloning (hanya 5\% yang menjawab benar) (Gambar 4). Mayoritas siswa menjawab teknologi kloning adalah teknologi yang berbahaya, merupakan tindakan kejahatan dan menyalahi aturan Tuhan. Selain itu pada soal yang lain siswa masih menganggap kloning tidak akan memberikan manfaat kepada manusia dan hanya akan membuat kerusakan di dunia. Akan tetapi mayoritas siswa mengetahui produk kloning seperti hormon insulin walau belum paham jika produk tersebut saat ini dihasilkan dari teknologi kloning. Persentase jawaban benaruntuk soal lainnya dalam pre-test secara berturut-turut adalah P2 37\%, P3 21\%, P4 95\%, P5 47\%, P6 21\% dan P7 95\%.

Hasil pre-test menunjukkan bahwa siswa masih banyak yang terjebak pada informasi hoax mengenai teknologi kloning. Siswa perlu diberikan pemahaman mengenai teknologi ini mengingat mereka adalah generasi yang kan menjadi penerus bangsa ini kedepannya. Mereka diharapkan akan menjadi agen-agen anti-hoax yang akan mengembalikan kemurnian informasi berlandaskan kebenaran sejati. Oleh karena itu tahapan kegiatan pengabdian masyarakat yang dilakukan selanjutnya adalah penyuluhan mengenai generasi anti-hoax. Dalam penyuluhan ini siswa diberikan pemahaman mengenai pentingnya filtrasi informasi sebelum disebarkan dan bahaya dari menyebarkan informasi hoax. Dari hasil diskusi mahasiswa mengaku banyak mendapatkan informasi saat ini dari media sosial dibanding referensi yang lebih dapat dipercaya. Hoax di dalam media sosial telah menjadi masalah yang serius di dunia termasuk di Indonesia (Satyawati et.al., 2019).

Setelah penyuluhan mengenai generasi anti-hoax dilakukan, siswa mendapatkan penyampaian materi terkait teknologi kloning. Untuk menyambung materi sebelumnya, penyampaian didahului tentang mitos atau pemahaman yang salah mengenai teknologi kloning. Beberapa pemahaman yang salah mengenai teknologi kloning yang umum terdapat di masyarakat antara lain :

a. Kloning adalah mesin duplikasi

Pemahaman ini biasanya muncul dari film-film populer di dunia. Beberapa film menunjukkan bahwa untuk menciptakan manusia bisa dilakukan dengan kloning seperti untuk menciptakan pasukan perang. Manusia yang akan dikloning dimasukkan ke dalam suatu mesin lalu akan muncul manusia baru di mesin yang lain. Pemahaman kloning semacam ini merupakan pemahaman yang salah. Kloning adalah sebuah teknologi yang prosesnya didasarkan pada ilmu bioteknologi.

b. Oganisme hasil kloning bukan makhluk hidup sesungguhnya

Pemahaman ini juga sangat keliru mengingat organisme hasil kloning terwujud dari proses pembiakan biologis layaknya oragnisme normal. Hal yang membedakan hanya bagian campur tangan manusia untuk menambah atau mengurangi beberapa bagian untuk menghasilkan organisme yang lebih baik.

c. Produk kloning hanyalah bagian dari organ tubuh sesungguhnya

Pemahaman ini masih berkaitan dengan pemahaman pada poin (b). Beberapa orang percaya bahwa produk kloning hanyalah berasal dari salah satu organ saja sehingga tidak bisa disebut makhluk hidup.

d. Kloning hanya dilakukan oleh ilmuwan gila Pemahaman ini juga biasanya diperoleh dari tokoh jahat di dunia perfilman. Tokoh seorang peneliti yang jahat dan gila akan penemuan untuk kejahatan bioasanya menjadi ilmuwan yang menciptakan duplikat manusia. Hal yang harus dipahami adalah teknologi kloning hanya bisa dilakukan oleh orang-orang yang memiliki keahlian khusus dengan pengawasan tingkat nasional atau internasional ekstra ketat dan fasilitas yang memadai. Perizinan untuk melakukan kloning juga sudah tertuang dalam peraturan terutama terkait bioetika. Hal tersebut menyebabkan teknologi ini tidak bisa dilakukan oleh sembarangan orang termasuk oleh ilmuwan gila. 
e. Kloning adalah perbuatan yang egois

Pemahaman ini juga berawal dari film populer seperti seseorang yang kehilangan orangyang berarti dalam hidupnya dan ingin menghidupkan kembali dengan teknologi kloning. Hal ini dianggap sebagai sifat egois oleh beberapa orang, apalagi kloning untuk tujuan kejahatan. Pemahaman ini sangatlah salah karena teknologi kloning saat ini hanya ditujukan untuk kemaslahatan manusia.

f. Kloning adalah sihir

Teknologi kloning merupakan ilmu pengetahuan di bidang bioteknologi. Teknologi ini tidak ada kaitannya dengan ilmu sihir. Kloning adalah murni sebuah ilmu pengetahuan yang dilakukan berdasarkan metode ilmiah.

g. Organisme hasil kloning memiliki umur yang pendek

Organisme hasil kloning adalah layaknya organisme normal sehingga tidak ada bukti ilmiah yang menunjukkan umurnya lebih pendek.

h. Kloning melawan hukum alam

Metode yang dilakukan dalam kloning didasarkan oleh fenomena yang terjadi secara alami. Oleh karena itu kloning justru sejalan dengan hukum alam.

Siswa juga diberikan pemahaman mengenai proses kloning secara sederhana. Analogi yang dilakukan adalah apabila kuning telur ayam berbulu cokelat ditukar dengan kuning telur ayam berbulu putih lalu dierami maka yang akan menetas adalah ayam berbulu putih. Inti sel makhluk hidup dapat dianalogikan sebagai kuning telur tersebut. Hanya saja dalam inti sel makhluk hidup tersusun atas DNA sebagai pembawa sifat yaitu gen. Setelah mendapatkan pengetahuan mengenai generasi anti-hoax dan teknologi kloning, siswa diajak melakukan simulasi kloning menggunakan media pembelajaran interaktif Lakon. Simulasi dilakukan oleh siswa dengan tim pendamping pengabdian masyarakat seperti yang ditunjukkan pada Gambar 3.

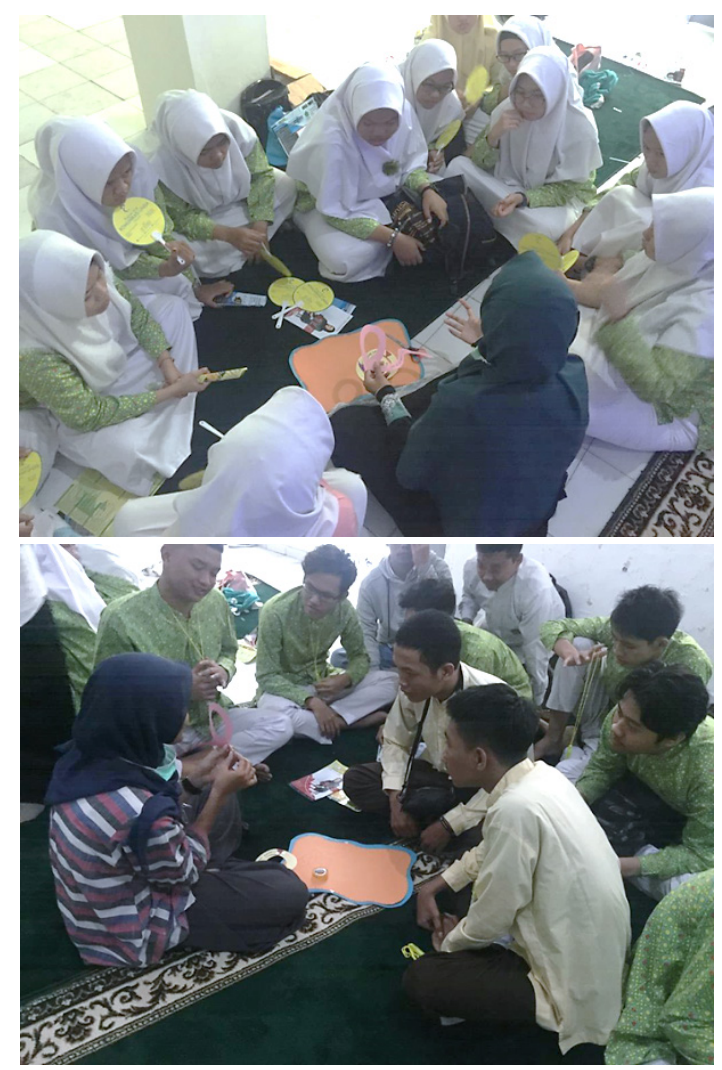

Gambar 3. Penerapan Lakon oleh siswa dengan tim pendamping

Diskusi dilakukan antara siswa dengan tim pendamping setelah dilakukan penerapan Lakon. Siswa dipersilahkan untuk menanyakan hal-hal yang belum dipahami baik mengenai generasi anti-hoax maupun teknologi kloning. Diskusi dalam kelompok kecil diharapkan akan memberikan pemahaman yang lebih baik pada siswa. Selain itu diharapkan siswa lebih bisa mengungkapkan pendapat ketika merasa segan menyampaikannya pada forum yang lebih besar. Pemahaman siswa mengenai teknologi kloning dieavluasi setelah Lakon selesai dipraktekkan melalui post-test. Evaluasi ini bertujuan untuk mengukur tingkat keefektifan dari media pembelajaran interaktif Lakon. Persentase jawaban benar dari hasil post-test adalah P1 79\%, P2 84\%, P3 74\%, P4 100\%, P5 84\%, P6 79\%, dan P7 100\% seperti yang tercantum pada Gambar 3. Rata-rata persentase kawaban benar pada saat post-test meningkat secara signifikan yaitu menjadi $85,71 \%$, hampir dua kali lipat dibandingkan dengan hasil pre-test (45,86\%). 


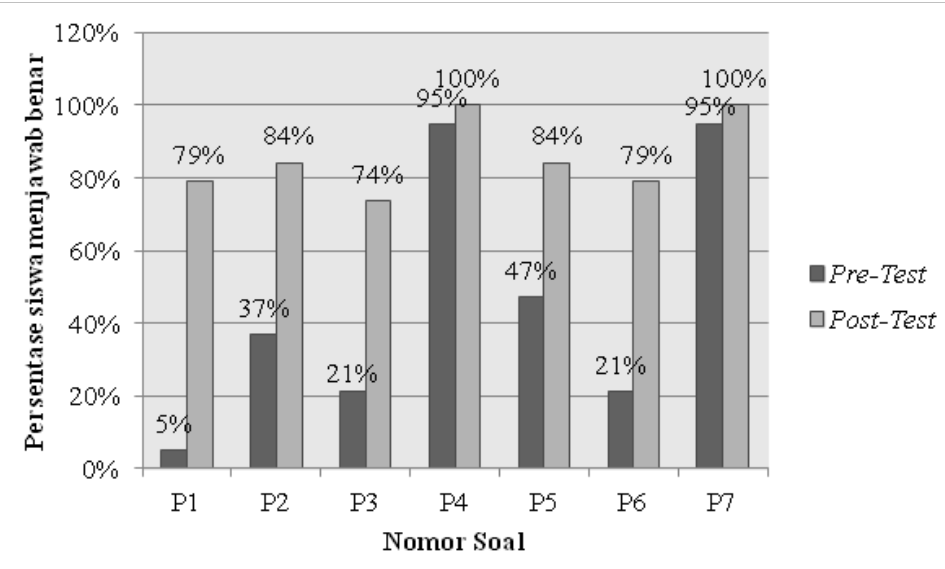

Gambar 3. Perbandingan persentase jawaban benar antara pre-test dan post-test

Berdasarkan hasil evaluasi, pelaksanaan program pelatihan media interaktif Lakon berhasil meningkatkan poemahaman siswa mengenai teknologi dengan cepat dan praktis. Metode ini sangat efektif untuk memberikan pemahaman yang benar sehingga siswa terhindar dan dapat membentengi diri dari hoax mengenai kloning. Setelah dilakukan proses penyuluhan dan belajar melalui media interaktif, informasi mengenai kloning membuka wawasan siswa terhadap pemahaman yang baru. Media interkatif lakon menjadi salah satu alat peraga yang user friendly bagi siswa dalam memahami teknologi kloning. Media ini diharapkan akan menjadi salah satu media bagi siswa untuk ikut serta dalam sosialisasi teknologi kloning di masyarakat. Siswa-siswa tersebut diharapkan menjadi agen-agen anti-hoax yang terbuka akan ilmu pengetahuan baru. Dalam jangka panjang media Lakon diharapkan dapat melahirkan generasi-generasi peneliti yang kritis terhadap kemajuan teknologi dan ilmu pengetahuan guna meningkatkan kualitas hidup bangsa Indonesia. Beberapa hal perlu menjadi perhatian dalam pelaksanaan pengabdian sejenis dengan sasaran siswa SMA/MA/SMK. Hal pertama adalah mengenai waktu pelaksanaan kegiatan utama akan lebih baik jika dilakukan dalam dua hari guna menghindari kejenuhan pada siswa dalam mengikuti penyuluhan. Hari pertama adalah pelaksanaan penyuluhan dilanjutkan dengan praktek pada hari kedua. Hal berikutnya yang perlu diperhatikan adalah memperkecil jumlah anggota kelompok dalam pelaksanaan praktek simulasi teknologi kloning. Anggota dalam satu kelompok siswa pada pengabdian ini terlalu besar yaitu 7-8 orang dalam satu kelompok. Hal tersebut mengakibatkan beberapa siswa merasa kurang maksimal dalam melakukan praktek. Jumlah anggota kelompok yang paling optimal dalam pelaksanaan pengabdian yang memerlukan praktek adalah 3 orang siswa.

MA Muhammadiyah Yogyakarta merupakan salah satu sekolah yang berwawasan agama Islam dan gerakan Muhammadiyah juga mendukung kegiatan ini dengan memberikan pernyataan bahwa:

1. Hasil pemikiran manusia dengan agama akan seimbang bila hasil pemikiran tersebut didasarkan pada sistem dan metode pemikiran yang benar, dan agama digali dengan daya ijtihad yang benar pula. Keduanya saling kuat-menguatkan.

2. Kloning ditinjau dari segi aspek teologis memperluas wawasan pengenalan terhadap kodrat iradat Ilahi, bahkan teknologi itu sebagai bukti keagungan Allah yang tertuang dalam ciptaan-Nya dan membuktikan ke Maha Kuasaan-Nya.

3. Kloning terhadap organ manusia dengan tujuan untuk dijadikan sumber organ transplantasi dapat dibenarkan sepanjang tidak bertentangan dengan tujuan syara.'

\section{SIMPULAN}

Proses pengabdian ini fokus pada media interaktif sebagai proses komunikasi yang menghadirkan transfer ide dan menerima ide baru untuk mendapatkan kesepakatan yang sama dengan siswa didik. Hasil evaluasi yang 
telah dilakukan dalam kegiatan ini menunjukkan bahwa dari proses persiapan sampai pada evaluasi, model pengabdian masyarakat ini berhasil menghadirkan metode pembelajaran yang baru untuk memberikan ranah keilmuan sains dan teknologi tanpa menyinggung atau menggunakan perspektif agama di dalamnya. Tim pengabdian menyadari masih banyak kekurangan dalam proses pengabdian ini antara lain terkait waktu pelaksanaan kegiatan utama yang perlu ditambah dan jumlah anggota kelompok siswa yang perlu dioptimalkan dalam kegiatan praktik. Secara teknis metode pengenalan kloning diharapkan mampu menjadi sarana pembelajaran yang interaktif, kreatif, dan efisien. Harapan selanjutnya adalah agar rekomendasi ini menjadi evaluasi untuk mengadakan program pengabdian ke masyarakat lebih lanjut. Model media pembelajaran ini diharapkan bisa diterapkan untuk sekolah (dalam hal ini MA Muhammadiyah Yogyakarta) sebagai media penumbuh ide baru yang interaktif.

\section{UCAPAN TERIMA KASIH}

Terima kasih kami ucapkan kepada LPPM Universitas 'Aisyiyah Yogyakarta yang telah memberikan fasilitas pendanaan untuk melakukan kegiatan masyarakat ini dan MA Muhammadiyah Yogyakarta yang telah bersedia menjadi mitra untuk mengembangkan metode pembelajaran dengan media interaktif ini dan telah menjadi tempat menguji produk pengabdian Lakon bagi SMA di Kota Yogyakarta.

\section{DAFTAR PUSTAKA}

Ayala, F. J. 2015. Cloning humans? Biological, Ethical, and Social Considerations. Proceedings of the National Academy of Sciences of the United States of America, 112(29) : 8879-8886.

Fajar, M. 2009. Dasar-Dasar Ilmu Komunikasi. Pustaka Utama: Jakarta, hal.31.

Hammond, L.D., Flook, L., Harvey, C.C., Barron, B. and Osher, D. 2020. Implications for Educational Practice of the Science of Learning and Development. Applied Developmental Science, 24(2):97140.

Khan, S., Ullah, M.W., Siddique, R., Nabi, G., Manan, S., Yousaf, M. and Hou, H. 2016. Role of Recombinant DNA Technology to Improve Life. International Journal of Genomics, 2016:14pp.

Klotzko, A. J. 2004. A Clone of Your Own? The Science and Ethics of Cloning. Oxford University Press:162 pp.

Maio, G. 2006. Cloning in the Media and Popular Culture. An Analysis of German Documentaries Reveals Beliefs and Prejudices that are Common Elsewhere. EMBO Reports, 7(3), 241-245.

Nurudin. 2016. Ilmu Komunikasi Ilmiah dan Popular. Rajagrafindo Persada: Jakarta, hal.17.

Prasetya, B. 2019. Regulasi Produk Rekayasa Genetik (PRG) di Indonesia "Posisi Sekarang dan Tantangan ke Depan”. FGD Pemanfaatan Bioteknologi Untuk Mendukung Pembangunan Pertanian Berkelanjutan. Ketua Komisi Keamanan Hayati Produk Rekayasa Genetika.

Reece, J. B., Urry, L. A., Cain, M. L. 1., Wasserman, S. A., Minorsky, P. V., Jackson, R., \& Campbell, N. A. 2014. Campbell Biology (Tenth edition). Boston:Pearson.

Satyawati, N.P., Utari, P. and Hastjarjo, S. 2019. Fact Checking of Hoaxes by Masyarakat Antifitnah Indonesia. International Journal of Multicultural and Multireligious Understanding, 6(6):159-172.

Souii, A., Ben M'hadheb, M., and Gharbi, J. 2013. Gene Cloning: A Frequently Used Technology in A Molecular Biology Laboratory - Alternative Approaches, Advantages and Limitations. American Journal of Research Communication, 1(5):18-35.

Wulff, H.J. 2001. Clone in Media. Medien Praktisch, 3:47-53. 